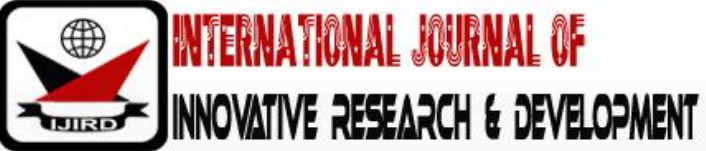

ISSN 2278 - 0211 (Online)

\section{Constraints to Performance of the Agricultural Cooperative Societies Services to Members in the Southern Agricultural Zone of Nasarawa State, Nigeria}

\author{
E. A. Ubana \\ Lecturer, Department of Agricultural Extension Technology, Federal College of Forestry, Jos, Nigeria \\ E.S Salau \\ Lecturer, Department of Agriculture, Nasarawa State University Keffi, Nigeria \\ A.A Girei \\ Lecturer, Department of Agriculture, Nasarawa State University Keffi, Nigeria
}

\begin{abstract}
:
The study examined the constraints to performance of the cooperative society's services to members in the Southern Agricultural Zone of Nasarawa State, Nigeria. A multistage sampling procedure was used to draw 150 cooperative society members as study sample. A structured questionnaire was used to obtain information on the membership and activities of the cooperative societies. Data were analyzed with descriptive statistical tools. The descriptive statistics used were percentages, mean scores, ranking and Likert type scale. Results showed that $42.0 \%$ of the respondents were between the ages of $31-40$ years, $28.0 \%$ of the respondents were between the ages $41-50$ years. The mean age of respondents was 40.5 years. Majority $(68.0 \%)$ of the respondents were married. About $(87.3 .0 \%)$ of the respondents had some form of formal education while only $(12.7 \%)$ of the respondents had no formal education. The mean agricultural enterprise experience of respondents was 12.5 years. The mean annual income of farmers in the study area was N411, 300:00. The mean size of cooperative society membership in the study area was 25 members. The mean annual savings of members in the study area was SN383, 533:00. The core activities of the cooperative societies were savings mobilization and loan disbursement $69.3 \%$, group farming activities $55.3 \%$ and farm inputs supply to members $44.7 \%$. Members derived benefits of cooperative societies in saving their money $78.7 \%$, easy access to credit $71.3 \%$ and in information sharing among members $67.3 \%$. The major constraints faced were lack of government support/ donor agencies with a mean score of 2.5 (very serious), poor supervision by government with a mean score of 2.3 (serious), poor transportation with a mean score of 2.3 (serious). It was therefore concluded that organize effort to mobilize rural farmers for cooperative spirit in the study area, and anywhere else, could assist to increase access to fund, farm inputs supply, dissemination of information and innovations, and reduce poverty. It was recommended that the cooperative members should be given the right incentives by government to intensify their participation in various cooperatives societies.
\end{abstract}

Keywords: Cooperative, cooperative society, agricultural society

\section{Introduction}

One of the major problems of agricultural development in Nigeria is that of developing appropriate organizations and institutions to mobilize and induce members of the rural sector to a greater productive effort (international cooperative alliance, ICA, (2010). Farmers are characterized by low income, low resources utilization, small farm holdings scattered nature of farmland, finds it difficult to pool their resource together to raise their farm income and substantially improve their standard of living. In situations like this cooperative represent a strong and viable economic alternative (ICA, 2010).

Cooperative is a business, voluntarily owned and controlled by its members patrons and operated for them, by them, on a non-profit basis. It is a business enterprise that aims at complete identity of the component factor of ownership control and use of services (Nweze, 2001). Cooperative is an autonomous association of persons unified voluntarily to meet their common economic, social and cultural needs through a jointly- owned and democratically controlled enterprise. (ICA, 2010). The performance of cooperative societies is highly dependent on its ability to tackle the following problems such as inadequate input supply, farm production technique, mechanization, processing, access to credit and extension services, storage facilities transportation, produce marketing and other social needs of the rural dwellers. This study, therefore undertakes the analysis of constraints to performance of the cooperative societies' services to members in the southern agricultural zone of Nassarwa State. 
The objectives of the study include to:

- Identify the socio-economic characteristics of the respondents.

- Identify the core activities of the selected cooperative groups

- Ascertain the benefits derived by members of cooperatives in the study area.

- Ascertain the constraints to effective performance of cooperative societies in the study area

\section{Methodology}

The study was conducted in southern agricultural zone of Nasarawa State. This comprises five (5) local government areas namely; Lafia Doma, Awe, Keana and Obi. In collaboration with Nasarawa State ministry of commerce, industries and cooperatives, a total of 42 registered agriculture cooperatives were selected. A multistage random sampling procedure was used to select the respondents. In the first stage, three (3) local government areas was purposively selected out of the five local government area, based on the predominance of registered agricultural cooperative societies. At the second stage, five (5) cooperative societies were randomly selected from each of the three (3) selected local government area. A total of 15 cooperative societies group was used. In the third stage, a purposive sampling technique was used to select five (5) key officials and 5 members from each of the selected group or cooperative societies, this gave a total of one hundred and fifty (150) respondents used for the study. Data for the study were collected from both primary and secondary sources. The primary data were collected using a well-structured questionnaire. Data for the study were analysed using descriptive statistics such as frequency counts, mean scores and percentages.

Specifically, frequently distribution tables and percentages, were used for objectives 1, ii and iii, while A three - point Likert scale with responses options of very serious (3), serious (2) and not serious (1) was used to measure the degree of performance of the cooperative societies

\section{Results and Discussion}

\subsection{Socio-Economic Characteristics of the Respondents}

\subsubsection{Age Distribution}

Results in Table 1 show that $42.0 \%$ of the respondents were aged between $31-40$ years, $28.0 \%$ of the respondents were aged between $41-50$ years, and $16.0 \%$ of the respondents were aged between 21 -30 years while $13.0 \%$ of the respondents were above 50 years. The mean age of the respondents was 40.5 years. This implies that respondents were relatively young and energetic farmers. This agrees with Nnadozie et al., (2015). Nigerian agricultural cooperatives and rural development IVO LGA, Ebonyi State, Nigeria

\subsection{Sex of Respondents}

Results in Table 1 reveal that majority (79.3\%) of the respondents were males while the remaining $20.7 \%$ of the respondents were females. The high percentage of male Cooperative members is probably due to the fact that agricultural activities are generally strenuous and women may not be fit enough to carry out the operations hence the high gender disparity.

\subsection{Level of Education}

The results further reveal that majority (87.3.0\%) of the respondents had some form of formal education while only $(12.7 \%)$ of the respondents had no formal education. This shows that education could be a significant indicator that can effectively mobilize cooperative group to attract government presence to assist the group. Education of members could also help to organize cooperative societies for an effective and efficient managements, which could help to bring back the already loss of trust and confidence in leaders. Udensi et al., (2014) revealed that education of members of a cooperative could lead to capacity building of members in areas of bookkeeping, recording, general administration of the group, as well as improved welfare packages for Members.

\subsection{Household Size}

Results show that $48 \%$ of the respondents had household size ranging from $6-10$ persons, $24.7 \%$ of the respondents had household size of 1-5 persons, and 20.0\% of the respondents had household size ranged from $11-15$ persons. The mean household size of respondents in the study area was 9 persons. This implies that respondents had relatively large family size. Therefore, respondents are expected to be engaged in reasonable occupation to be able to fend for their families.

\subsection{Marital Status}

The marital distributions of respondents show that majorities (68\%) of the respondents were married, $12.0 \%$ were single, $7.3 \%$ were widowed and the remaining $1.3 \%$ of the respondents was divorced. Marriage was generally accepted as a symbol of maturity and status of responsibility. Respondents who are married are more likely to participate in agricultural activities than unmarried ones. According to Kimaru et al., (2015), married farmers normally opt to participate in agricultural activities in order to fulfill their daily family socio-economic needs. 


\subsection{Agricultural Enterprise Experience}

Results in Table 1 also show that about $45.4 \%$ of the respondents had agricultural enterprise experience of between 1-10 years, $28.0 \%$ of the respondents had agricultural enterprise experience of between 11-20 years while $26.6 \%$ of the respondents had enterprise experience of more than 20 years, the mean years of agricultural enterprise experience was 12.5 years. This implies that most respondents had some level of experience in agricultural enterprises in the study area. Agricultural enterprise experience is very important because it determines the ability of the farmers to make effective management decision on the enterprise. This also implies that there is likelihood of high productivity and good decision making in agricultural enterprises which in turn increase output, income and better standard of living.

\subsection{Annual Income}

The results on farm income showed that majority (54.7\%) of the respondents had between $\mathrm{N} 1,000$ - N400,000 as annual income, 37.3\% of the respondents had between N401,000 - N800,000:00 while $6.0 \%$ of the respondents had more than N1,200,000 annual income The mean annual income of the respondents was N411,300:00. This shows a very low-income level of members of the cooperative society implying that cooperative members in the study area were low income earners operating at the subsistence level.

\subsection{Duration of Cooperative Membership}

Results in Table 1 show that $40.0 \%$ of the respondents had been in co-operative business for $1-5$ years, $36.7 \%$ of the respondents had spent6-10 years, and 14.0\% of the respondent had been in co-operative business for 11-15 years. The mean years of cooperative membership was 5 years. This implies that many of the Farmers Cooperatives Societies in the study area have not been in existence long enough. Years of farmers' cooperatives society's existence is a strong factor that can be used to determine their level of maturity in fulfilling their core mandates or functions to their members.

\subsection{Membership Size of Cooperative}

Results show that majority (74.0\%) of the cooperative societies had 20-40 members, $20.0 \%$ of the cooperative societies had less than 20 members. The mean size of cooperative society membership in the study area was 25 members. This implies membership strength in the study was low. Membership strength has been viewed as one of the factors that influence the performance of any cooperative societies. This implies that reasonable membership strength has great effect on the performance of the cooperative societies, because this will help them to pool their resources together to be able to access more resources which might be difficult for them to get individually because of the financial implications. These resources can then be used for their farming activities which might invariably enhance their productivity.

\subsection{Total Annual Savings of Members}

Results in Table 1 show that majority (81.3\%) of the respondents saved between 1,000-500,000 naira, 17.3\% of the respondents saved between $501,000-1,000,000$ naira while $0.7 \%$ of the respondents saved between 1,001,000$1,500,000$ naira and 1,501,000-2,000,000 naira. The mean annual savings of members in the study area was 383,533 naira. The annual savings of cooperative members in the study area was low. This indicates that there is still need for improvement in the cooperators saving attitude in order to increase the volume of funds available for funding of members' projects. This could also be attributed to the size of agricultural enterprise(s) that one has.

\begin{tabular}{|c|c|c|c|}
\hline Variable & Frequency & Percentage (\%) & Mean \\
\hline Age & 1 & 0.7 & \\
<21 years & 24 & 16.0 & \\
21-30 years & 63 & 42.0 & 40.5 years \\
31-40 years & 42 & 28.0 & \\
41-50 years & 20 & 13.0 & \\
$>50$ years & 31 & 20.7 & \\
Fex & 119 & 79.3 & \\
Male & 18 & 12.0 & \\
Marital status & 119 & 79.3 & \\
Single & 2 & 1.3 & \\
Married & 11 & 7.3 & \\
Divorced/ separated & 19 & 12.7 & \\
Widowed & 15 & 10.0 & \\
Level of education & 41 & 27.3 & \\
Non-formal education & 39 & 26.0 & \\
Primary school education & 34 & 22.7 & \\
Secondary school education & 2 & 1.3 & \\
ND/ NCE education & & & \\
HND/ DEGREE & & & \\
MSc/ Phd & & & \\
& & & \\
\hline
\end{tabular}




\begin{tabular}{|c|c|c|c|}
\hline Variable & Frequency & Percentage (\%) & Mean \\
\hline $\begin{array}{c}\text { Enterprise experience } \\
1-10 \\
11-20 \\
\text { Above } 20 \text { years }\end{array}$ & $\begin{array}{l}68 \\
42 \\
40\end{array}$ & $\begin{array}{l}45.4 \\
28.0 \\
26.6\end{array}$ & 12.5 vears \\
\hline $\begin{array}{c}\text { Annual income fin naira }(\mathrm{N})\} \\
1,000-400,000 \\
401,000-800,000 \\
801,000-1,200,000 \\
>1,200,000\end{array}$ & $\begin{array}{c}82 \\
56 \\
3 \\
9\end{array}$ & $\begin{array}{c}54.7 \\
37.3 \\
2.0 \\
6.0\end{array}$ & N411,300 \\
\hline $\begin{array}{l}\text { Major agric enterprises } \\
\text { Crop production } \\
\text { Mixed farming } \\
\text { Livestock production } \\
\text { Agric produce marketing } \\
\text { Agro processing } \\
\text { Farm input marketing }\end{array}$ & $\begin{array}{l}71 \\
48 \\
15 \\
9 \\
3 \\
4\end{array}$ & $\begin{array}{c}47.3 \\
32.0 \\
10.0 \\
6.0 \\
2.0 \\
2.7\end{array}$ & \\
\hline $\begin{array}{c}\text { Duration of cooperative membership } \\
1-5 \text { years } \\
6-10 \text { years } \\
11-15 \text { years } \\
\text { Above } 15 \text { years }\end{array}$ & $\begin{array}{l}94 \\
42 \\
8 \\
6\end{array}$ & $\begin{array}{c}62.7 \\
28.0 \\
5.3 \\
4\end{array}$ & 5 years \\
\hline $\begin{array}{c}\text { Amount of annual Cooperative savings (N) } \\
1,000-500,000 \\
501,000-1,000,000 \\
1,001,000-1,500,000 \\
1,501,000-2,000,000\end{array}$ & $\begin{array}{c}122 \\
20 \\
1 \\
1\end{array}$ & $\begin{array}{l}81.3 \\
17.3 \\
0.7 \\
0.7\end{array}$ & $\begin{array}{c}\text { N383,533:00 } \\
\text { naira }\end{array}$ \\
\hline Total & 150 & 100.0 & \\
\hline
\end{tabular}

Table 1: Distribution of Respondents Based on Socio-Economic Characteristics (N=150) Source: Field Survey (2018). N=Sample Size

\subsection{Core Activities of the Cooperative}

Results in Table 2 show that the core activities of the cooperative societies were savings mobilization and loan disbursement (69.3\%), group farming activities (55.3\%), farm inputs supply to members (44.7\%), processing of members' farm produce (35.3\%), marketing of members' farm produce (29.3\%), provision of storage facilities for members (25.3\%), transport services for members (21.3\%) provision of extension services/ training workshop (12.0\%) and sales of essential commodities to members (11.3\%)S. The results show that cooperatives provided loans to members, farm inputs were easily obtained because members had easy access to credit. Consistent or regular provision of loans to members, easy access to farm inputs and easy access to credit will help boost farm productivity of members.

\begin{tabular}{|c|c|c|}
\hline Core Activities of the Cooperative Groups & Frequency & Percentage (\%) \\
\hline Savings mobilization and loan disbursement & 104 & 69.3 \\
Group farming activities & 83 & 55.3 \\
Farm inputs supply to members & 69 & 44.7 \\
Processing of members' farm produce & 53 & 35.3 \\
Marketing of members' farm produce & 44 & 29.3 \\
Provision of storage facilities for members & 38 & 25.3 \\
Transport services for members & 32 & 21.3 \\
Provision of extension services/ training workshop & 18 & 12.0 \\
Sales of essential commodities to members & 17 & 11.3 \\
\hline
\end{tabular}

Table 2: Core Activities of the Cooperative Groups

Source: Field Survey 2018

Multiple Responses

\subsection{Benefits Derived from Cooperatives by Members}

Results in Table 4 show that members of cooperative societies derived benefits in the following areas: Opportunity f for savings (28.7\%), essay access to credit (25.3\%), information sharing among members (17.3\%), interest/dividend from savings (12.0\%), marketing of members' products (12.0\%), benefits from government interventions (8.0\%), education of members through adult education/ seminar/ workshop (8.0\%), provision of production inputs/ equipment (6.7\%), provision of processing/storage/ transport facilities (3.3\%) and socialization/networking 
(1.3\%). The major benefits derived by cooperative members were avenue for savings, essay access to credit and information sharing among members.

\begin{tabular}{|c|c|c|c|}
\hline Benefit & Frequency & Percentage (\%) & Rank \\
\hline Avenue for savings & 118 & 78.7 & $1^{\text {st }}$ \\
\hline Easy access to credit & 107 & 71.3 & $2^{\text {nd }}$ \\
\hline Information sharing among members & 101 & 67.3 & 3rd \\
\hline Interest/ dividend from savings & 18 & 12.0 & $4^{\text {th }}$ \\
\hline Marketing of members' products & 18 & 12.0 & 4th \\
\hline Benefitting from government interventions & 12 & 8.0 & 5th \\
\hline Education of members through adult education/ seminar/ workshop & 12 & 8.0 & 5th \\
\hline Provision of production inputs/ equipment & 10 & 6.7 & $6^{\text {th }}$ \\
\hline Provision of processing/ storage/ transport facilities & 5 & 3.3 & $7^{\text {th }}$ \\
\hline Socialization/ networking & 2 & 1.3 & $8^{\text {th }}$ \\
\hline
\end{tabular}

Table 3: Benefits Derived from Cooperative Society by Respondents

Source: Field Survey 2018

Multiple Responses

\subsection{Constraints to Effective Performance of Agricultural Cooperative Societies}

The results in Table 5 suggest that cooperative societies in the study area were faced with a number of constraints. The most serious constraints faced were lack of government support/ donor agencies with $(x=2.5)$ poor supervision by government with $(\mathrm{x}=2.3)$, poor transportation with $(\mathrm{x}=2.3)$ and lack of storage and processing facilities with $(x=2.2)$. Other constraints faced were inadequate finance/low savings with $(x=1.9)$, high level of illiteracy among members with $(x=1.7)$, high interest rate on loans with $(x=1.7)$, lack of cooperative education/ awareness with $(x=1.6)$, small membership size with $(x=1.6)$, lack of gender equity in leadership with $(x=1.5)$, conflicts of interest among members with $(x=1.5)$, poor record keeping with $(x=1.5)$, default in repayment loans with $(x=1.5)$, lack of commitment by members with $(x=1.4)$, poor service delivery to members with $(x=1.4)$, lack of effective leadership with $(x=1.3)$ and corruption among officials with $(\mathrm{x}=1.2)$. David (2016) identified the constraints to effective performance of Agricultural co-operatives in Akwa North Local Government Area of Anambra State, Nigeria to include: inadequate capital accumulation, unavailability of loan, mis-management by leaders, lack of skilled personal, high rate of loan default, high illiterate level of member, corrupt and fraudulent officers, lack of co-operative and technical education and inadequate infrastructural facilities .

\begin{tabular}{|c|c|}
\hline Constraint & Mean score \\
\hline lack of government support/ donor agencies & 2.5 \\
\hline poor supervision by government & 2.3 \\
\hline poor transportation facilities & 2.3 \\
\hline lack of storage and processing facilities & 2.2 \\
\hline inadequate finance/ low savings & 1.9 \\
\hline high level of illiteracy among members & 1.7 \\
\hline high interest rate on loans & 1.7 \\
\hline lack of cooperative education/ awareness & 1.6 \\
\hline small membership size & 1.6 \\
\hline lack of gender equity in leadership & 1.5 \\
\hline conflicts of interest among members & 1.5 \\
\hline poor record keeping & 1.5 \\
\hline default in repayment loans & 1.5 \\
\hline lack of commitment by members & 1.4 \\
\hline poor service delivery to members & 1.4 \\
\hline lack of effective leadership & 1.3 \\
\hline corruption among officials & 1.2 \\
\hline
\end{tabular}

Table 4: Constraints to the Effective Performance of

Agricultural Cooperative Societies MS = Mean Score

Source: Field Survey (2018)

\section{Conclusion and Recommendations}

Results revealed that the core activities of the cooperative societies were savings mobilization and loan disbursement $69.3 \%$, group farming activities $55.3 \%$ and farm inputs supply to members $44.7 \%$. Results also revealed that members of cooperative societies derived benefits in the following: avenue for savings 78.7\%, easy access to credit $71.3 \%$ and information sharing among members $67.3 \%$. However, the major constraints faced by Co-operators were lack of 
government support/ donor agencies with a mean score of 2.5 (very serious), poor supervision by government with a mean score of 2.3 (serious) and poor transportation with a mean score of 2.3 (serious).

It was recommended that the cooperative members should be given the right incentives by government to intensify their participation in various cooperatives societies.

\section{Reference}

i. Arua, E. O., (2004). Comparative Cooperative System. Unpublished Departmental Mimeograph. Department of Agricultural Economics, University of Nigeria, Nsukka.

ii. Augustine, M. (2016). Assessment of the Factors Influencing the Performance of Agricultural Cooperatives Gatsibo District, Rwanda. international journal of information research and review vol. 03, issue, 09, pp. 2755-2763.

iii. Bhuyan, S., (2007). "The People Factor in Cooperatives"; An Analysis of Members, Canadian Journal of Agricultural Economics, 55(3): 275-298.

iv. Borgens, S. O., (2001). Identification as a Trust-generating Mechanism in Cooperatives". Annual Publication of Cooperative Economics.

v. David, S.J. (2016). Contributions of Co-operative to Agricultural Development a study of AgriculturalCo-operative in Akwa North Local Government Area.

vi. Ebonyi, V. \& Jimoh, O. B., (2002) Cooperative Movements; A way out of Poverty. Lagos, Lonman Publishers.

vii. Ibitoye, S.J (2012). Survey of the Performance of Agricultural Cooperative Societies in Kogi State,Nigeria. European Scientific Journal October edition vol. 8, No.24

viii. ICA. (2010). International Cooperative Alliance. Retrieved 1, October, 2011 from http:// www.ica.coop/ .ss.

ix. Kimaru P., Towo, N., \& Moshi, B. (2015). Determinants of rural youth's participation in agricultural activities: the case of Kahe east ward in Moshi rural district, Tanzania. International Journal of Economics, Commerce and Management ISSN 23480386 Vol. III, Issue 2, February 2015.69.

x. Levi, Y. (2005). A Cooperative Perspective, Ireland: International Cooperative Research Institute.

xi. Nnadozie, A.K.O., Oyediran, A.G., Njoku, A.G and Okoli, A.C (2015). Nigeria agricultural cooperatives and rural development in IVO Local government area of Eboyi State, Nigeria. Global Journal of Management and Business Research: G Interdisciplinary, Vol 15 issue 4 Version. 1.02015

xii. Nweze, N.J (2001). Poverty, Microfinance and Cooperative Promotion in Nigeria. Nigerian Journal of Cooperative Studies, (1): 2-5.

xiii. Onah, O.G. (2014). Assessment of the Performance of Farmers' Multipurpose Cooperative Societies in Enugu North Agricultural Zones of Enugu State, Nigeria. ResearchGate. https:/ / www.researchgate.net/ publication/ 324703653

xiv. Onouha, E (2002). A critique of the drafts of cooperative policy for Nigeria. Nigeria Journal of Cooperative Studies, $2(1): 10-17$.

xv. Udensi, L. O. I, Felix N. P, Johnny k. Cand Esther, O. (2014). The Role of Craft and Artisan Cooperative Societies in the Socio-Economic Advancement of Its Members in Abia State, Nigeria. Mediterranean Journal of Social Sciences MCSER Publishing, Rome-Italy Vol 5 No 2. 